


\title{
Features of detection and obtaining evidence of war crimes committed in the context of international armed conflict
}

\author{
DOI: https://doi.org/10.46398/cuestpol.3969.04
}

Tataryn Ihor *

Komissarchuk Yuliia **

Dmytryk Yurii ***

Maistrenko Mariia ****

Rymarchuk Olha $* * * *$

\begin{abstract}
The scientific article is devoted to a comprehensive understanding of international legal, procedural, and organizational problems of investigation of war crimes committed during the military conflict in the south and east of Ukraine. It develops the author's concept of investigation of war crimes committed during the armed conflict, scientifically substantiated theoretical provisions and specific patterns that are manifested in the field of legal support, organization of investigation, collection of evidence, methods of investigation of crimes of this type. It is concluded that there is a need to specify the components of war crimes in national legislation. Recommendations for further improvement of criminal and criminal procedure legislation of Ukraine in order to fulfill the state's international obligations in the field of international humanitarian law are given.
\end{abstract}

Keywords: war crimes; investigation; international armed conflict: gathering of evidence; investigative (search) actions.

* Candidate of legal sciences, Associate Professor, Senior teacher at the Department of Criminal Procedure and Criminalistics, Lviv State University of Internal Affairs, Lviv, Ukraine. ORCID ID: https://orcid.org/oooo-0002-9517-2299. Email: ttihor@ukr.net

** Candidate of legal sciences, Associate Professor, Associate Professor at the Department of Criminal Procedure and Criminalistics, Lviv State University of Internal Affairs, Lviv, Ukraine. ORCID ID: https://orcid.org/oooo-0o02-5079-334X. Email: juliyakomis@gmail.com

*** Candidate of legal sciences, Associate Professor, Associate Professor of the Department of Operativesearch Activity, Lviv State University of Internal Affairs, Lviv, Ukraine. ORCID ID: https://orcid. org/oooo-0003-3929-3544. Email: tibet@ukr.net

**** Candidate of legal sciences, Senior teacher at the Department of Criminal Procedure and Criminalistics, Lviv State University of Internal Affairs, Lviv, Ukraine. ORCID ID: https://orcid.org/oooo-00026996-7186. Email: justmarisabel2017@gmail.com

***** Candidate of legal sciences, Associate Professor at the Department of Criminal Process, National Academy of Internal Affairs, Kyiv, Ukraine. ORCID ID: https://orcid.org/oooo-0003-0062-9645. Email: olgaRUM@ukr.net 


\section{Características de la detección y obtención de pruebas de crímenes de guerra cometidos en el contexto de un conflicto armado internacional}

\section{Resumen}

El artículo científico está dedicado a una comprensión integral de los problemas legales, de procedimiento y organizativos internacionales de la investigación de los crímenes de guerra cometidos durante el conflicto militar en el sur y este de Ucrania. Desarrolla el concepto de investigación del autor de los crímenes de guerra cometidos durante el conflicto armado, disposiciones teóricas fundamentadas científicamente y patrones específicos que se manifiestan en el campo del sustento legal, organización de la investigación, recolección de pruebas, métodos de investigación de crímenes de este tipo. Se concluye que es necesario especificar los componentes de los crímenes de guerra en la legislación nacional de Ucrania. Se dan recomendaciones para seguir mejorando la legislación de procedimiento penal y penal de Ucrania con el fin de cumplir con las obligaciones internacionales del estado en el campo del derecho internacional humanitario.

Palabras clave: crímenes de guerra; investigación; conflicto armado internacional; recolección de pruebas; acciones de investigación (allanamiento).

\section{Introduction}

The priority in the use of military force to resolve disputed nationalethical, religious, political, territorial, economic, and other contradictions remains among the essential features of modern reality. In five and a half millennia of the history of human civilization, there have been about 15,000 wars and armed conflicts, in which more than 3.5 billion people have died. Throughout its history, people have lived in peace for only 292 years, less than one week every hundred years (Vakhrushev, 1999).

Despite the ratification by the international community of various conventions on international humanitarian law and the fight against their violations, as well as their partial implementation and nationally established criminal liability for war crimes, virtually all wars and armed conflicts are accompanied by the commission of the most serious war crimes.

Almost everywhere in areas of armed conflict, there is a violation of the laws and customs of war, the use of prohibited means and methods of warfare, related to the violation of the principles of selectivity, 
Tataryn Ihor, Komissarchuk Yuliia, Dmytryk Yurii, Maistrenko Mariia y Rymarchuk Olha

proportionality allowed in the process of missile and artillery, and aviation missile strikes, recruitment, training, financing and (or) the use of mercenaries in hostilities, the destruction of settlements, executions in the form of premeditated killings for political, ideological, racial, national, religious hatred or enmity, torture and other inhuman treatment and other atrocities which are inherently cruel. All the crimes mentioned above cannot remain unpunished.

Unfortunately, a significant part of criminal offenses remains unpunished, and those responsible for them are not prosecuted using state sovereignty. At the same time, the legal prospects for punishing criminals are not entirely clear (Grigoryan, 2018). Personnel policy and gaps in the manning of the defense forces are also acute problems. A critical factor is the shortcomings in the fight against corruption in management and the executive branch, as evidenced by the resonant scandals in law enforcement agencies and the defense industry (Corruption in Defense - continuation Argument, 2019).

The confrontation in Donbas is one of the key challenges to Ukraine's national security. Despite the declared ceasefire, the Ukrainian military suffers daily casualties. Thus, the problem of criminal prosecution of representatives of the military-politicalleadership andindividual servicemen for committing war crimes during the armed conflict initiated and provoked by the aggressor is relevant for both Ukraine and other countries. Several organizational and tactical issues related to the investigation of crimes in this category also need to be addressed.

\section{Methodology of the study}

A comprehensive study of war crimes is possible only by combining different methodological studies. The general scientific methods used in the scientific article include a dialectical method, a deductive and a system method, methods of analysis and synthesis.

The dialectical method of scientific cognition is a general and universal method of forming legal concepts, it is a cognitive strategy that aims to identify the causes, origins, and consequences of the studied phenomena, their internal contradictions, connections, and relationships with other phenomena. With the help of this method, it became possible to learn the content of such categories as "war crimes", "armed conflict", "gathering evidence" and others. Methods of analysis and synthesis allowed to select and analyze information on the research topic.

The essence of the system method is that the process of investigating war crimes is considered as a certain system, which is included in the system of 
a broader order, performs certain functions, and is associated with various connections. The systematic approach provided an opportunity to analyze investigative and judicial practice, criminal cases, decisions of the European Court of Human Rights in war crimes cases.

Special scientific methods used in writing a scientific article include a hermeneutic, a formal-legal method, modeling and forecasting, sociological and statistical methods.

The application of the hermeneutic method allowed to qualitatively analyze and clarify the content of legal documents, including the provisions of the Criminal Code of Ukraine and the Criminal Procedure Code of Ukraine, which regulate the relevant legal relations in the study area. The formal-legal method was used to formulate and interpret legal concepts and categories. Sociological and statistical methods are used in the process of studying the materials of criminal proceedings and generalization of scientific results, the study of law enforcement practice. Modeling and forecasting methods were used to formulate proposals for improving certain provisions of the Criminal Code, the Criminal Procedure Code of Ukraine.

Thus, the author's methodology of this study is a set of methods and techniques based on a dialectical analysis of legal documents, empirical data, as well as a critical understanding of the scientific literature on this issue.

\section{Analysis of the recent research}

Some theoretical and practical aspects of criminal liability, procedures for investigating war crimes committed in armed conflict were considered in the works of such scientists as Schwarzenberger G. (1968), Furkalo V.V. (1982), Raskaley S.B. (1985), Belyy I. Yu. (2004), Simpson G. (2007), Grigoryan G.M. (2009), Eliseev R.A. (2011), Skuratova A.Yu. (2012), Mokhonchuk S.M. (2014), Rusinova V.N (2015), Mykhaylenko V.S (2017), Koval D.O. and Avramenko R.A. (2019), Mazur M.V. (2020), Tkachenko P.I. (2020), Chervyakova, O.V. (2020), and other authors.

However, there are some issues that need comprehensive analysis and coverage. In particular, the issues of legislative regulation of legal relations in the context of international armed conflict, including the criminalization of certain illegal acts, need an additional solution. It is necessary to improve methodological approaches to the evaluation of legal programs and the entire legal system in Ukraine, interpretation of the decisions of the European Court of Human Rights, their use in investigative and judicial practice (Matvieieva et al., 2021). It is also indisputable that certain tactical and procedural "tools" for the investigation of war crimes committed in the 
Tataryn Ihor, Komissarchuk Yuliia, Dmytryk Yurii, Maistrenko Mariia y Rymarchuk Olha

context of an international armed conflict must be properly disclosed from the standpoint of forensic science and criminal procedure.

\section{Results and discussion}

Given that war crimes can only be committed in the course of or in connection with an armed conflict, it would be logical to clarify its nature. Undoubtedly, armed conflict in all its manifestations is a deformation of social relations, accompanied by sharp contradictions, widespread use of weapons, the declining value of human life, rising levels of violence and other crime, which is the root cause of war crimes.

An international armed conflict occurs when an attack on the territory of a state is carried out by another state, or by non-governmental formations under the control of another state. In this case, the international armed conflict begins to be used after the first shot against the territory of a state or crossing the border by the armed forces of another state. The conflict will also be considered international if the third country has at least general control over non-governmental armed groups. An occupation of the territory of another state is equated to an armed conflict of an international character, even if such an occupation does not meet with armed resistance (Koval and Avramenko, 2019).

The investigation of war crimes committed by participants in an armed conflict is usually carried out in a combat situation caused by hostilities in areas of armed conflict (Grigoryan G., pp. 33-36). Influencing all aspects of life, the combat situation affects the investigation of war crimes, complicating a number of destructive factors in the process of detection, detection and investigation of war crimes, identifying specifically stable links, dependencies, relationships and trends in this area.

Based on this, it can be argued that there are specific patterns of investigation of war crimes committed in the eastern and southern territories of Ukraine in the context of international armed conflict.

According to S.V. Malikov, there are two directions of influence of negative factors caused by the armed conflict on the organization and methods of investigation of war crimes: direct influence on its organization and methods, as well as influence through the special nature of war crimes committed in armed conflict (Malikov, 1998).

The process of investigating war crimes is also affected by the negative factors caused by the international armed conflict:

- national, ethnic, religious, or territorial causes of armed conflict, as well as often rather "vague" definition of the parties to the conflict's purpose; 
- ignorance and unwillingness of political leaders and the command of the parties to the conflict to adhere to the norms of international law;

- Insufficient objective information about the armed conflict, mutual distrust of the opposing parties and the operation of a set of unproven and sometimes "senseless" accusations;

- the use of political means by political leaders, military command and media representatives of opposing parties with the use of euphemisms (liquidation, cleansing, action, operation, etc.), which mask the real goals and use of prohibited means and methods of hostilities by the parties;

- a pronounced division of society into supporters of the relevant side of the conflict;

- justification by the opposing parties of the criminal actions of their armed supporters or combatants by the circumstances and military necessity, by reference to the actions of the opponent's country;

- ignorance by combatants of the opposing parties of the norms of international law and national norms of the Criminal Code, confidence in impunity, lack of effective sanctions by the command to subordinates;

- Insufficient advocacy and information of the public, government agencies and officials, marginalization and stigmatization of victims;

- increasing the level of public danger of war crimes committed by the parties to an armed conflict, as well as their consequences;

- the emergence of crimes that encroach on specific legal relations arising in connection with an armed conflict (in a combat situation, on the battlefield, in the area of hostilities);

- committing serious violent crimes against representatives of the opponent's country out of revenge;

- the dependence of the level of a war crime on the duration, intensity, scale of the armed conflict, its economic and political consequences, as well as the number of dead; $n$ ) the number and scale of war crimes, as well as the steady increase in the level of war crime;

- the response of war crime to the military successes or failures of another party to the conflict, as well as the high level of artificially latent war crime;

- the response of war crime to the military successes or failures of another party to the conflict, as well as the high level of artificially latent war crime; 
Tataryn Ihor, Komissarchuk Yuliia, Dmytryk Yurii, Maistrenko Mariia y Rymarchuk Olha Features of detection and obtaining evidence of war crimes committed in the context of

- a significant number of crimes directly or indirectly related to the presence of weapons in the warring parties, as well as the use of modern methods and means of remote control of hostilities;

- committing war crimes in a state of alcohol or drug intoxication.

Of course, in order to eliminate or minimize the consequences of the above negative factors for the investigation of war crimes committed in the context of international armed conflict, it is necessary to take measures to improve information policy to prevent violations of international law.

War crimes are one of the most serious and serious crimes known to mankind. Under international law, the state in which war crimes are committed (Nazarchuk, 2020) is the most active in conducting investigations and bringing perpetrators to justice. However, at present, Ukraine is not always able to adequately respond to hostilities in the temporarily occupied and adjacent territories. For example, in the Criminal Code of Ukraine, in addition to Art. 438, there are no detailed rules that determine the illegality of certain actions in a military conflict. There is also no explanation of what war crimes are, which are light, medium, severe, and the degree of responsibility. This problem needs a comprehensive solution. Some lawyers rightly consider the adoption of the law on transitional justice (Bida, 2021) to be a way out of this situation.

Objective principles of determining the grounds for the application (criminalization) or refusal to apply (decriminalization) of criminal law influence should be recognized as a constant problem of criminal law (Kozachenko et al., 2021). It must be stated that those guilty of committing most war crimes today, unfortunately, manage to avoid criminal prosecution. One of the reasons is the imperfection of the legislation and its inconsistency with international norms. Current Art. 438 of the Criminal Code of Ukraine ("Violation of the laws and customs of war") is quite generalized, so there is an obvious need to specify the composition of war crimes in national law, defining all serious violations of international humanitarian law as war crimes. Thus, there is an obvious need to specify the components of war crimes in national legislation (Nazarchuk, 2020).

Thus, the realities of today in the East and South of Ukraine indicate the imperfection of certain provisions of the Criminal Code of Ukraine, in particular the lack of legal norms that would correspond to the socially dangerous act committed in the area of the anti-terrorist operation. Currently, there is an urgent need to revise the sections of sections XIX-XX of the Code in order to include in their composition the rules that would provide for criminal liability for all actions against the interests of the people of Ukraine.

In our opinion, for the effective work of the institutions of executive power in Ukraine in this direction, there are not enough legislative tools 
that would promote more constructive work and increase responsibility and accountability for actions and measures taken that would be: expected signals for citizens of Ukraine in the occupation or were forced to leave the occupied territory; signals for collaborators and violators of the sanctions regime about the inevitability of liability for actions committed; the leadership of other countries and international organizations, as a confirmation of the sequence of actions of the Ukrainian authorities, in its pursuit of de-occupation and reintegration of temporarily lost territories.

When applying Art. 438 (Violation of the laws and customs of war) of the Criminal Code of Ukraine (Criminal Code of Ukraine, 2001) it is necessary to focus on the practice of international criminal courts, doctrine, authoritative comments on international economic law, and the provisions of international treaties. However, the list of acts that may be considered violations of the laws and customs of war does not necessarily coincide with the list of Art. 8 of the Rome Statute or a list of serious violations of international economic law. It can be extended, but not arbitrarily. In any case, the expansion of the list of these acts should find support in international practice. Otherwise, Ukraine will almost certainly face cases against itself in the European Court of Human Rights.

Due to the above-mentioned information, we propose to focus on the list of acts that can be classified as violations of the laws and customs of war, proposed in the bill "On Amendments to Certain Legislative Acts of Ukraine to Harmonize Criminal Law with International Law” № 9438 (DRAFT LAW OF UKRAINE, 2018). This list is in line with international standards and Ukraine's obligations under international treaties to criminalize violations of international humanitarian law.

One of the significant steps aimed at improving the efficiency of the investigation of war crimes, including those committed in the context of international armed conflict, is the signing by the Prosecutor General of Ukraine on October 21, 2019 of an order establishing the Department of Supervision of Criminal Proceedings. armed conflict, whose activities will focus on overseeing the investigation of crimes committed in the temporarily occupied territory of the Autonomous Republic of Crimea and the city of Sevastopol, in the temporarily occupied areas of Donetsk and Lugansk regions and in armed conflict (Department for war crimes has been established in the Prosecutor's Office of Ukraine). All this creates a vertical for coordinating the efforts of all law enforcement agencies in the investigation of war crimes and crimes against humanity, which will contribute to the systematic recording and systematization of evidence.

Concluding the consideration of the conceptual issues of improving the state of the fight against war crimes in the context of international armed conflict, we turn to the study of the peculiarities of detection and collection of evidence during the investigation of these crimes. 
Tataryn Ihor, Komissarchuk Yuliia, Dmytryk Yurii, Maistrenko Marïa y Rymarchuk Olha Features of detection and obtaining evidence of war crimes committed in the context of international armed conflict

Procedural and organizational aspects of the investigation of war crimes committed in armed conflict currently remain one of the least developed problems in the theory of criminal procedure and international law (Vinokurov, 2011). In our view, unlike the criminal process in its usual sense, the implementation of the war crimes investigation procedure needs to be revised and improved.

We share the position of G.M. Grigoryan, who points out that the complexity and multifaceted problem of determining the procedural order of investigation of war crimes is due to the following features: a high degree of interference in the internal affairs of the state, which significantly affect the national interests of the other side of the armed conflict; the prosecution of persons who have committed war crimes in the territory of another country-participant to the armed conflict and fall within its jurisdiction in particular; one of the parties in whose territory the crime was committed, for some reason, does not provide an objective and qualified investigation, and in some cases opposes the investigation; limited ability to gather evidence in the territory of the opponent's country, when there are some witnesses, suspects, etc.; lack of legal regulation of the grounds and procedure for conducting investigative and other procedural actions on the territory of the other party to the conflict; the inevitable conflict of constitutional, procedural and substantive norms in force in the territory of the parties to the conflict; non-fulfillment by the parties of requests for international legal assistance, etc. (Grigoryan, 2018).

A fundamental feature of the procedural order of investigation of war crimes is that the perpetrators belong to the parties to the conflict, and to establish the involvement of specific servicemen (pilots, gunners, snipers, etc.) of the other party who gave and carried out airstrike orders, artillery shelling and destruction of civilians, other war crimes, proof of guilt, etc. It is believed that national investigative bodies, guided solely by the provisions of the Criminal Procedure Code of Ukraine, without effective international law and mechanisms for investigating such crimes, without investigative and procedural actions in the territory and with the participation of the other party to the armed conflict or lack of truce, will not be able to use the potential of criminal procedural means and to ensure the investigation and prosecution of other parties to the conflict responsible for war crimes unless military-violent scenarios are considered, which are purely hypothetical.

At the same time, after instituting criminal proceedings in this category under the principle of extraterritorial criminal jurisdiction, at the stage of investigation and presentation of evidence to representatives of the other party to the conflict, national law enforcement agencies face the problem of limiting their powers under the national Criminal Procedure Code. At the same time, the fact of instituting a criminal case against representatives of the other side of the conflict does not yet indicate that any of them will 
be prosecuted. This problem goes beyond the capabilities of the national Criminal Procedure Code or giving international treaties legal force within the legal system of Ukraine.

Attention will be paid to some problems that arise in the qualification of war crimes committed in an international armed conflict. The qualification of war crimes and the full use of international humanitarian law should be based on an objective criterion, namely the existence of an international armed conflict, and not on the geographical element or status of the belligerents, as there is no reason why non-international victims of armed conflicts should be treated differently from victims of international armed conflicts, recognizing similar acts as war crimes in some cases and not in others. At the same time, there is a direct dependence of the qualification of war crimes committed by the parties to the armed confrontation on its nature. Based on the above, we analyze the nature of the armed conflict in the south and east of Ukraine, which, in our opinion, has all the characteristics of an armed conflict of an international nature, and qualifies as international.

Vinokurov A. Yu. rightly notes that the process of qualifying war crimes is three main successive stages. The first establishes the presence of material elements (acts, consequences and other circumstances specified in the definition of a war crime). Concerning war crimes and crimes against humanity, armed conflict or an attack on the civilian population are considered to be significant circumstances. The second establishes the presence of a mental element, which determines that the material elements were committed "intentionally and consciously." The third establishes the existence of circumstances that preclude criminal liability. Besides, it is necessary to establish which violations of international humanitarian law took place and under what conditions it will lead to the individual criminal liability of an individual (Vinokurov, 2011).

At the initial stage of the investigation, the investigator's extremely important task is to find out which unit involved in the conflict committed the crime. This requires proof of the link between the incident and the armed conflict, in particular: confirmation of the fact that the commanders of certain military structures organized, coordinated, or planned military operations of the unit, that they are funded, trained, equipped and directed by government officials. It should be noted that crimes committed by the military against its own army/unit cannot be qualified as war crimes (Koval and Avramenko, 2019).

The investigator also needs to find out whether the victim belongs to one of the categories of protected persons, which include: the wounded; prisoners of war; civilians. Intentional homicide, torture or inhuman treatment, intentional infliction of severe suffering or serious bodily injury or damage to health, large-scale destruction and misappropriation 
Tataryn Ihor, Komissarchuk Yuliia, Dmytryk Yurii, Maistrenko Marïa y Rymarchuk Olha Features of detection and obtaining evidence of war crimes committed in the context of

of property not caused by military necessity, etc., committed against such persons are war crimes.

The organization of the work of the investigative group has certain peculiarities, which depend on the following circumstances: the initial investigative situation; the stage of the initial or subsequent investigation; investigators who are a part of the investigative team, their experience in investigating crimes of this type; how many witnesses need to be questioned; seizure and inspection of the amount of combat and operational documentation to be carried out.

A feature of the investigation of crimes committed by servicemen in the area of anti-terrorist operation / joint forces operation on the eastern and southern borders of Ukraine is the detection and investigation of crimes "in hot pursuit" and the use of group (brigade) investigation to improve the quality and efficiency of investigation.

Therefore, the need to establish an investigative team in the investigation of criminal cases of this category may arise both at the initial and subsequent stages of the investigation. In our opinion, only such a method of investigation is most acceptable in the temporarily occupied and adjacent territories of Ukraine and is the only one possible to improve the quality of the investigation of war crimes. The main task of the investigation "in hot pursuit" is to quickly identify the person who committed the crime, and in favorable cases, his detention as a result of immediate primary and urgent investigative actions and operational and investigative measures (Yablokov, 2003).

The possibility of applying the method of investigation "in hot pursuit" is due to the peculiarities of the investigative situations of the initial stage of the investigation and depends on the following factors: the insignificance of the time elapsed from its commitment to the beginning of the investigation; preservation of the material situation at the crime scene in full or without significant changes; the existence of unfavorable objective and subjective conditions that prevent the preservation of the material situation of the scene and its traces in the same form; the possibility of immediate search and search activities in a specific relatively localized area of the crime; availability of means of rapid notification and immediate arrival of the investigative task force to the crime scene; availability of technical and forensic means of working with traces in the mode of "express analysis"; appropriate professional level of investigators.

Based on the general plan of the investigation and taking into account the individual instructions of the head of the investigation team, each member of the investigation team draws up a detailed individual plan of their work. As for the peculiarities of the organization of the work of the investigative team, they depend on the following circumstances: the initial investigative 
situation; the stage of the initial or subsequent investigation; investigators who are part of the investigative team, their experience in investigating crimes of this type; how many witnesses need to be questioned; seizure and inspection of the amount of combat and operational documentation to be carried out.

Particular attention needs to be paid to the study of the peculiarities of the collection of evidence of war crimes committed in the context of an international armed conflict by authorized participants in criminal proceedings. First of all, it is a question of carrying out such investigative (search) actions as inspection of a scene and interrogation.

Obtaining and recording evidence during the investigation of artillery attacks in the study of impact craters is an important step in determining the direction from which was fired. The fired areas must be inspected as soon as possible. Craters are quickly exposed to the elements and the intervention of military and civilians, losing their value as a source of information.

The main task of the investigator on arrival at the place of fire is to isolate and fence among other ditches those that will give the most information about the origin of the attack. The main thing is to clarify with witnesses and see for yourself that it was formed during the shelling, the fact of which is being investigated. At the scene, the investigator should: set the coordinates of the place of fire, make a panoramic video of the scene (Koval and Avramenko, 2019).

The procedure of interrogation during the pre-trial investigation has its characteristics due to the conditions of the combat situation. In the area of armed conflict, investigators must conduct this investigative (investigative) action most competently, fully and exhaustively, using control and detailed questions, because the conditions of the combat situation may not allow additional or repeated interrogation in connection with death, injury, captivity. or a business trip of the interrogated serviceman.

Analysis of the investigative practice of military investigative bodies shows that in most cases interrogations are conducted descriptively and in sufficient detail about all the circumstances directly related to the criminal case. However, investigators do not take sufficient measures to verify the testimony of the interrogated, do not ask control questions. As a result, a fairly complete and rich interrogation report is obtained, which contains important testimonies for the case, but it is impossible to judge how reliable these testimonies are by such an interrogation report. This error is always negatively reflected throughout the investigation, but it is especially negative for the practice of military investigative bodies in the area of armed conflict, where the opportunity to find any evidence other than the testimony of the interrogated person is extremely limited (Grigoryan, 2009).

In addition, in contrast to the interrogation conducted in peacetime, 
Tataryn Ihor, Komissarchuk Yuliia, Dmytryk Yurii, Maistrenko Mariia y Rymarchuk Olha Features of detection and obtaining evidence of war crimes committed in the context of international armed conflict

the interrogation in a combat situation, in our opinion, is complicated by the situation of obtaining evidence (mobile forensic laboratory, dugout, tent, shell funnel, ruins, trench, shelter or other inconvenient premises or terrain). This situation often does not contribute to the establishment of psychological contact with the interrogated and does not create a favorable atmosphere for the investigative (search) action.

One of the main tactics of interrogation used in the investigation of war crimes in the area of anti-terrorist operation / joint force operation in Ukraine. Regardless of whether the investigator has doubts about the objectivity of the testimony of the interrogated, should be detailing these testimonies, as the formulation of detailed and control questions in order to clarify and verify the circumstances of the criminal offense is extremely important.

In a combat situation, the time for interrogation is limited, and therefore the list of interrogation tactics used is limited. Therefore, during the interrogation, the investigator must, in the shortest possible time, obtain the maximum amount of evidentiary "express information" necessary for the organization of the investigation, including on "hot leads". Hence the relative "brevity" of the interrogation protocols, which often reflect only the main circumstances of the investigated event and there are no answers to which are detailed and control questions to clarify and verify the testimony.

In areas of armed conflict, the investigator must take into account and assess the mental, emotional and psychological state of the interrogated, as well as the possible consequences of combat mental injuries received during hostilities or as a result of war crimes, and choose the most appropriate and procedural acceptable tactics for obtaining evidence.

Thus, the use of these methods of interrogation will allow the investigator to prepare for the interrogation, which, in our opinion, will allow him to establish with maximum completeness and accuracy the circumstances of the evidence in criminal proceedings, to determine in advance the choice of tactics, sequence of questions work out several versions. In addition, the use of a common standard interrogation program by investigators will help, rationally using time, to draw up an individual interrogation plan for the specific investigative situation of the initial or subsequent stage of the investigation, the specific circumstances of the criminal case and the individual.

The process of gathering evidence can be optimized only by adapting to the conditions of the armed conflict of the certifying party of this procedure. Strengthen the evidence side and at the same time provide a "shorter" and secure access to sources of evidence can be only done by using new technologies to capture information. However, not all investigative (search) actions held in peacetime can be carried out quickly and successfully in areas 
of armed conflict. We believe that in order to adapt them, some changes in the procedure are needed to simplify certain investigative (search) actions, provided that formalism is avoided and the purpose and semantic essence of these methods of gathering evidence during the pre-trial investigation are taken into account.

\section{Conclusions}

Based on the results of the problems covered in the scientific article, we can draw some conclusions. In our opinion, the need to specify the components of war crimes in national legislation is obvious. Pre-trial investigation bodies, guided only by the provisions of the national Criminal Procedure Code, without taking into account international law and mechanisms for investigating war crimes, without conducting investigative and procedural actions on the territory and with the participation of the other party to the armed conflict or procedural means and to ensure the quality of the investigation and the possibility of prosecuting the representatives of the other side of the conflict responsible for such illegal actions. National law enforcement agencies should extend criminal law to perpetrators outside the state and exercise their criminal jurisdiction over representatives of the country initiating the armed conflict based on the principle of passive citizenship, which provides for the extension of criminal law depending on the nationality of the victim or the principle of protection, which provides for the spread of criminal law of the state depending on whether the interests and security of the state are violated.

Increasing the investigation of war crimes committed in the context of international armed conflict is the detection and investigation of crimes "in hot pursuit" and the use of group (brigade) method of investigation to improve the quality and efficiency of the investigation. Only such a method of investigation is most acceptable in an armed conflict and is the only one possible to improve the quality of the investigation of war crimes.

We consider it necessary to develop methodological recommendations for the investigation of certain types of war crimes and an algorithm for conducting some investigative (search) and other procedural actions, as the effectiveness and quality of investigation of war crimes, including those committed by armed parties, is achieved by effective investigation planning and rationalization. investigative (search) actions in order to neutralize or reduce the impact of destructive factors of armed conflict on the investigation of these illegal acts. 
Tataryn Ihor, Komissarchuk Yuliia, Dmytryk Yurii, Maistrenko Mariia y Rymarchuk Olha Features of detection and obtaining evidence of war crimes committed in the context of

\section{Bibliographic References}

RUSINOVA, Vera. 2015. Human Rights in armed conflicts: problems of correlation between International Humanitarian Law and International Human Rights Law. Monograph. Moscow, Russia.

SKURATOVA, Alexandra. 2012. International Crimes: modern problems of qualification. Moscow, Russia.

ELISEEV, Roman. 2011. International criminal law: features of legal implementation: dissertation of the candidate of legal sciences. Moscow, Russia.

BELYY, Igor. 2004. International prosecution for war crimes (legal and procedural aspects). Monograph. Moscow, Russia.

RASKALEY, Sergey. 1985. Objective responsibility of states in international law. Kyiv, Ukraine.

SCHWARZENBERGER, Georg. 1968. International Law as Applied by International Courts and Tribunals. Vol. II: The Law of Armed Conflict. London. P. 462.

SIMPSON, Gerry. 2007. Law, war and crime: war crimes trials and the reinvention of international law. Cambridge, England.

FURKALO, Vladimir. 1982. International legal protection of civilians during armed conflicts: author's abstract of the dissertation of the candidate of legal sciences. Kyiv, Ukraine.

GRIGORYAN, Guyk. 2009. Investigation of Crimes Committed by the Servicemen of the Armed Forces of the Republic of Armenia in the Areas of the Armed Conflict: dissertation of the candidate of legal sciences. Moscow, Russia.

KOVAL, Dmytro; AVRAMENKO, Roman. 2019. War crimes. Features of the investigation of international crimes committed in the context of the armed conflict in Donbas. Kyiv. Ukraine. Available online. In: https:// truth-hounds.org/wp-content/uploads/2019/12/\%Do\%92\%Do\%BE\% D1\%94\%Do\%BD\%Do\%BD\%D1\%96-\%Do\%B7\%Do\%BB\%Do\%BE\% D1\%87\%Do\%B8\%Do\%BD\%Do\%B8-Truth-Hounds.pdf. Consultation date: $06 / 11 / 2020$.

CHERVYAKOVA, Oksana. 2020. "Responsibility for war crimes: mechanisms and processes of restoring the sovereignty and security of Ukraine" In: Law Forum. No. 61(2). pp. 150-162. 
MYKHAYLENKO, Volodymyr. 2017. War crimes in international law: Basic research on the application of transitional justice in Ukraine: a monograph. Kyiv, Ukraine.

MAZUR, Mykola. 2020. Criminal proceedings on crimes related to the occupation of Crimea and the conflict in Donbas, under the procedure in absentia: current status and prospects for improvement. Available online. In: https://supreme.court.gov.ua/userfiles/media/22_05_2020_M_ Mazyr_1.pdf. Consultation date: 06/11/2020.

MOKHONCHUK, Serhiy. 2014. Criminal-legal protection of peace and security of mankind: author's abstract of the dissertation of the candidate of legal sciences. Kharkiv, Ukraine.

KOZACHENKO, Oleksandr; SOTULA, Oleksandr; BIBLENKO, Vasyl; GIULYAKOV Kostiantyn; BEREZNIAKOV Oleksandr. 2021 "The substrate of criminal-legal influence.” In: CUESTIONES POLÍTICAS Vol. 39, No. 68, P. 443.

MATVIEIEVA, Liliia; BALTADZHY, Polina; SHMALENKO, Iuliia; YEFTIENI, Natalia; IVANCHENKO, Olga. 2021. "Legal protection of vulnerable groups of population: practice of the European Court of Human Rights". In: CUESTIONES POLÍTICAS Vol. 39, No. 68, P. 138.

VINOKUROV, Aleksandr. 2011. "International legal, theoretical and organizational basis of criminal prosecution for war crimes against civilians" In: NAUKARUS. Available online. In: http://naukarus. com/a-yu-vinokurov-mezhdunarodno-pravovye-teoreticheskie-iorganizatsionnye-osnovy-ugolovnogo-presledovaniya-za-sovershenie-v. Consultation date: 06/11/2020.

MALIKOV, Sergey. 1998. Legal and organizational foundations of the investigation of crimes committed by servicemen in the areas of armed conflict: dissertation of the candidate of legal sciences. Moscow, Russia.

VAKHRUSHEV, Victor. 1999. "Local wars and armed conflicts: character and influence on military art" In: Military Academy of Military Sciences. Military thought. Available online. In: http://militaryarticle.ru/ zarubezhnoe-voennoe-obozrenie/1999-zvo/8988-lokalnye-vojny-ivooruzhennye-konflikty-harakter-i. Consultation date: 06/11/2020.

GRIGORYAN, Guyk. 2018. International legal framework for the investigation of war crimes. (Based on the materials of the Nagorno-Karabakh armed conflict). Monograph. Yerevan, Armenia. 
Tataryn Ihor, Komissarchuk Yuliia, Dmytryk Yurii, Maistrenko Marïa y Rymarchuk Olha Features of detection and obtaining evidence of war crimes committed in the context of international armed conflict

YABLOKOV, Nikolay. 2003. Criminalistics. Moscow, Russia.

BIDA, Olexii. 2021. Documenting war crimes is a natural process of restoring justice. Online article. Available online. In: https://helsinki.org. ua/articles/oleksiy-bida-dokumentuvannia-voiennykh-zlochynivpryrodniy-protses-vidnovlennia-spravedlyvosti. Consultation date: 06/03/2021.

NAZARCHUK, Iryna. 2020. War crimes in Donbas. What are the difficulties of investigating and bringing the perpetrators to justice? Online article. Available online. In: https://www.radiosvoboda.org/a/war-crimedonbas-problems/30733783.html. Consultation date: 06/11/2020.

DEPARTMENT FOR WAR CRIMES HAS BEEN ESTABLISHED IN THE PROSECUTOR'S OFFICE OF UKRAINE. 2019. Online article. Available online. In: https://mtot.gov.ua/v-gpu-stvoreno-departament-zviskovih-zlochiniv. Consultation date: 06/11/2020.

CORRUPTION IN DEFENSE - CONTINUATION - ARGUMENT. 2019. Online article. Available online. In: http://argumentua.com/video/korupts-yav-oboronts-prodovzhennya-gladkovskiisvinarchuk-ukroboronprom-tamna-perepiska Consultation date: 06/11/2020.

TKACHENKO, Pavlo. 2020. "Forensic characteristics of war crimes." In: Scientific conference: Achievements and achievements of applied and fundamental sciences of the XXI century. On August 7. Cherkasy, Ukraine. pp. 117-120. Available online. In: https://ojs.ukrlogos.in.ua/index.php/ mcnd/article/view/4253/4191. Consultation date: 06/11/2020.

CRIMINAL CODE OF UKRAINE. 2001. On April 05. Available online. In: https://zakon.rada.gov.ua/laws/show/2341-14. Consultation date: 06/11/2020.

DRAFT LAW OF UKRAINE: On Amendments to Certain Legislative Acts of Ukraine Concerning Ensuring Harmonization of Criminal Legislation with Provisions of International Law. 2018. On December 20. No 9438. Available online. In: http://w1.c1.rada.gov.ua/pls/zweb2/ webproc4_1?pf3511=65266. Consultation date: 06/11/2020. 
Vol. 39 N $^{\circ} 69$

Esta revista fue editada en formato digital y publicada en julio de 2021, por el Fondo Editorial Serbiluz, Universidad del Zulia. Maracaibo-Venezuela 